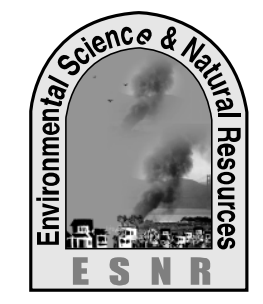

J. Environ. Sci. \& Natural Resources, 7(1): 189 - 196, 2014

ISSN 1999-7361

\title{
Ecotourism Potentiality in the Dulahazra Safari Park, Bangladesh
}

\author{
A. Hossen' ${ }^{1}$ M. F. Ahsan ${ }^{2}$ and M. Kamruzzaman ${ }^{3}$ \\ ${ }^{1}$ Department of Biology, Norwegian University of Science and Technology, Norway \\ ${ }^{2}$ Department of Zoology, University of Chittagong, Bangladesh \\ ${ }^{3}$ Center for Environmental and Geographic Information Services (CEGIS), Gulshan, \\ Bangladesh (Corresponding author)
}

\begin{abstract}
In this research we explore the potentiality of ecotourism in a safari park as a new concept under South-Asian model with dynamic perspective comparing to other ecotourism destinations in Bangladesh. The research reveals that Safari Park is not only spotlighted ecotourism activities for recreation but it also plays a vital role to protect natural pristine with rich biological diversity. Besides, Safari Park concept in Bangladesh considered as a revenue source for government and socio-economic benefits to the local communities. It is, however, resource to students as well as researchers.
\end{abstract}

Key Words: Biodiversity, Ecotourism, Education, Local Community, Research, Revenue

\section{Introduction}

Tourism refer to passing good time in an aesthetic destination with amusing moments for short time on the purpose of free from busy and dogmatic life which refresh body and mind even inspires newly enter into working life. Tourism mainly focus on mass tourism although different form of tourism emerging in modern life such as rural tourism, green tourism, heritage tourism, cultural tourism, industrial tourism, health tourism, political tourism and volunteer tourism. There are some various between tourism and adventure travel regarding to level of risks and uncertainty. Adventure travel is two types including soft and hard but both are contain different degree of risks and adverse situation whereas adventure travel contain risk and uncertainty, mass tourism having detrimental to environment with unsustainable way, the ecotourism illuminate environmental friendly, support to local livelihood diversification and nature conservation with sustainable way (Shamuddoha and Nasir 2011). Ecotourism can participate to increase green productivity, infrastructure development to remote area and employment rate increase to local community by considering as a market based product. As ecotourism is a formation of tourism, so the actual definition of ecotourism will be really tough regarding to thoughts, principles and characteristics of ecotourism. Ecotourism defined by McCormick (1994) "purposeful travel to natural areas to understand culture and natural history of the environment, taking care not to alter the integrity of the ecotourism, while producing economic opportunities that make the conservation of natural resources beneficial to local people". The ecotourism definition delimited by the international ecotourism society: "responsible travel to natural areas that conserves the environmental and improves the well being of local people". Ecotourism may be nature, culture and heritage based. Nature based ecotourism is the most prominent than culture and heritage. Nature based tourism emphasis to natural scenery, topography, water features, plants and animals regarding to all natural resources except man made resources. Ecotourism also focuses on scientific investigation, education, recreation and awareness to all kind of biological diversity. Ascribed by Catar (1994), ecotourism improves life expectation to local community and helps to receive socio-economic benefits from this sector. Since ecotourism introduced new way to local community for proliferated their financial status so, combine effort from local community and ecotourists generate positive attitude towards conserve biological resources even natural resources (Drake 1991). Moreover, revenue from proper use of natural resources by considering conservation and sustainable development with diversified, magnified and stable economy gaining from ecotourism.

\section{Study Area}

Safari Park is a new concept as a specialized protected area along with eco-park in Bangladesh except other three protected areas including national park, wildlife sanctuary and game reserve. This park also consider as a recreation park for vast potentiality of ecotourism. The Dulahazra Safari Park is pioneer in Bangladesh refer to most famous Asian and African Safari Park concept. Dulahazra Safari Park is located in Dulahazra forest range under Cox's Bazaar north forest division and $107 \mathrm{~km}$ away from port city Chittagong under Chakoria upazila of Cox's Bazar district (Biwas 2001, Khan 1990, Balmforth 1987). 
This park is surrounded by Fasiakhali forest rang under Cox's Bazar north forest division and geographic location refers 21406.7 to $21406.9 \mathrm{~N}$ latitude and 92468.44 to 92468.48 E longitudes (Map 1). The altitude is almost $9 \mathrm{~m}$ from the sea level. The topographic landscape of Dulahazra Safari Park is undulated hilly area with green and semi-green coverage. Many depressions, narrow valleys and perennial natural streams flow inside park which contain good quality of water for the year round. This park is enriched by wild, semi-wild and captive wild animals along with native vast flora. Some non-native ornamental plants also exist there.

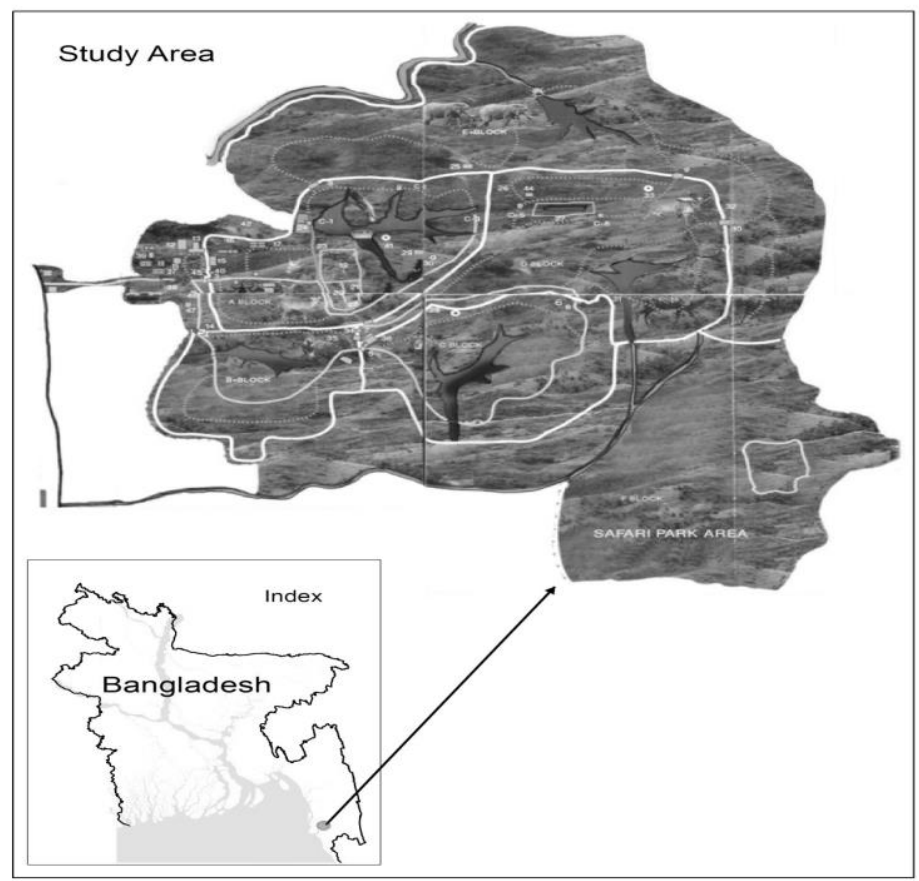

Map 1: Dulahazra Safari Park, Cox's Bazar

\section{Materials and Methods}

Ecotourism potentiality was measured and evolution based on tourists interest and opinion about ecotourism opportunity in Safari Parks. Per year tourists increase rate is being reflected to flourished ecotourism in Dulahazra Safari Park. For this purpose, the total number of visitors was counted and interviewed 720 by supporting semistructured questionnaire during study from June 2007 to May 2008. The visitor's number was counted regarding total number of ticket selling per day to per month in this park. During my research work, interviewed was taken from ten visitors in a day including six days in a month. During interview, visitors were categorized by native and non-native, district-wise, agegroup, occupation, and education-level. The age groups were categorized as children ( $<10$ years), juvenile ( $<20$ years), young $(>20$ years) and adult $(>30$ years). Ecotourism relevant information also gathered from staffs and local communities adjacent to the Safari Park. Moreover, visitors' activities were recorded to extract their rate of interest behind the perspectives of ecotourism.

\section{Results and Discussions}

\section{Visitor numbers and monthly fluctuation}

The total domestic visitors were 774524 comparing to 262 foreign visitors found during June 2007 to May 2008 in the 
Dulahazra Safari Park (Table 1). The number of foreign ecotourists was negligible rather than domestic. The highest number of ecotourists visited in the month of January and lowest in August and gradually decreased by January to May in 2008 even the same result found from June to September in 2007 (Table 1). The foreign ecotourist ratio was increased from January to February than other consecutive months in 2007 and 2008. The remarkable domestic ecotourists were varied comparing to six civil districts who visited the park from June 2007 to May 2008. The highest number come from Chittagong district (42\%), lowest from Khulna (4\%), the second highest from Dhaka and Shylhet (10\%), Barisal (9\%) and Rajshahi (5\%) (Figure 1a).

Table 1(a). Monthly domestic and foreign eco-tourists fluctuation rate in Dulahazra Safari Park

\begin{tabular}{|l|l|l|l|l|}
\hline Year & Month & Domestic visitor & Foreign visitor & Total \\
\hline \multirow{5}{*}{2007} & June & 40,130 & 7 & 40137 \\
\cline { 2 - 5 } & July & 35405 & 15 & 35420 \\
\cline { 2 - 5 } & August & 30536 & 20 & 30556 \\
\cline { 2 - 5 } & September & 16335 & 14 & 16349 \\
\cline { 2 - 5 } & Ctober & 102021 & 25 & 102046 \\
\cline { 2 - 5 } & November & 75847 & 18 & 75865 \\
\cline { 2 - 5 } & December & 65327 & 25 & 65352 \\
\hline \multirow{5}{*}{2008} & January & 111878 & 30 & 111908 \\
\cline { 2 - 5 } & February & 101395 & 40 & 101435 \\
\cline { 2 - 5 } & March & 105452 & 35 & 505487 \\
\cline { 2 - 5 } & April & 50246 & 18 & 39967 \\
\cline { 2 - 5 } & May & 39952 & $\mathbf{7 7 6 7 8 6}$ \\
\hline & Total & $\mathbf{7 7 4 5 2 4}$ & $\mathbf{2 6 2}$ & \\
\hline
\end{tabular}

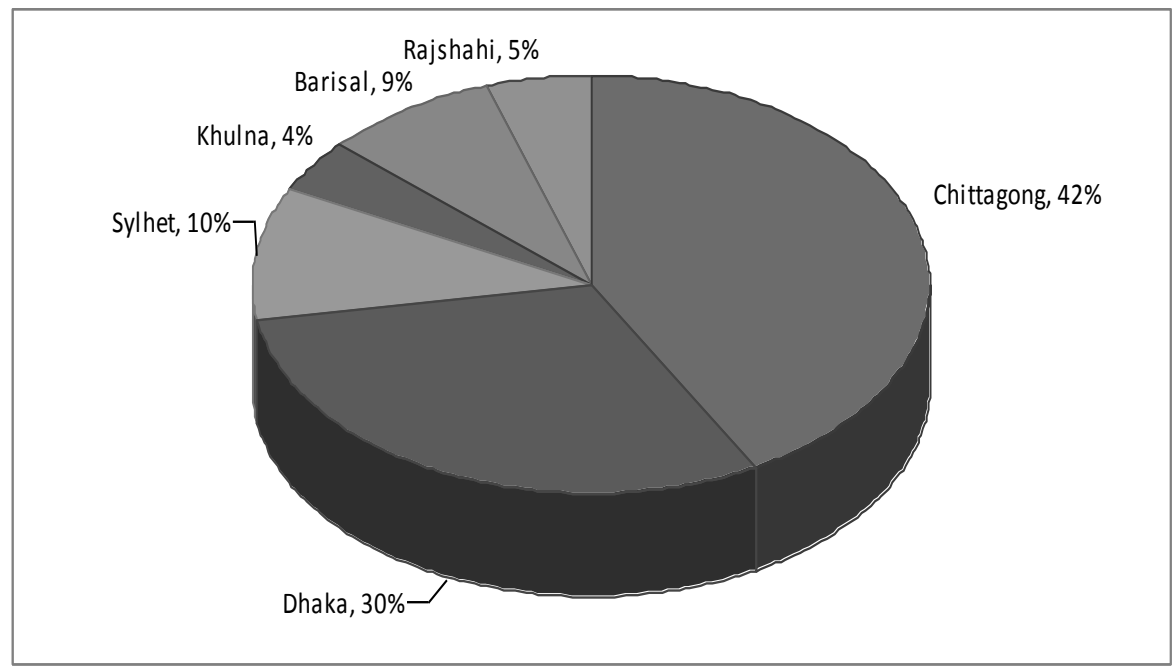

Fig: 1a. Ecotourist gathering rate in safari park from different civil divisions in Bangladesh 


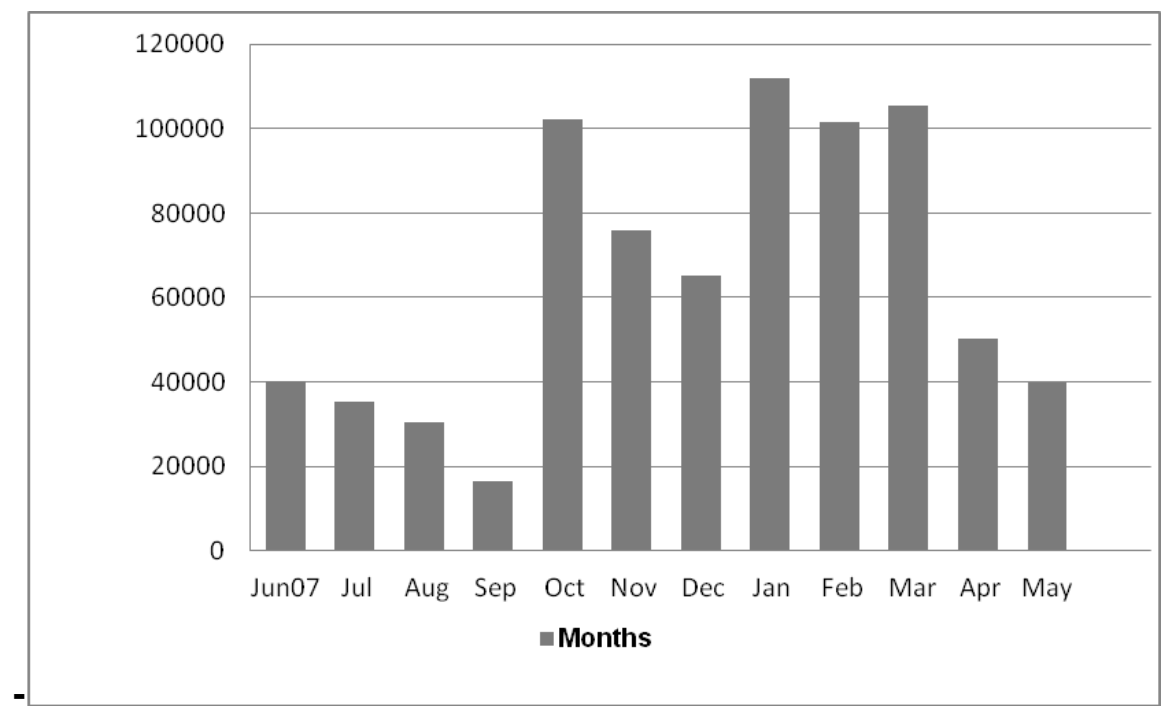

Fig 1b: Total visitor numbers fluctuated according to different months in a year

Safari Park as the best ecotourism site: There is an enormous potentiality of Safari Park to be tourist attraction than other parks including eco-park, national park and recreational park (Table 1). The Safari Park concept in Bangladesh is totally different from other parks based on their characteristics. Safari Park concept varied continent to continent, region to region even country to country due to geographical condition and environmental characteristics. For example, African Safari Park is a unique characteristic due to savanna forest comparing to rainforest in South America and pine forest in Europe and North America. Most of Indian Safari Parks are charismatic single wildlife based including tiger safari in bungalow and elephant safari in Andhra province (Thampi 2005). In Bangladesh, Safari Park is being established target to multipurpose use of natural resources including protection of wildlife, vegetation, topography and natural pristine (Dey 2002). In Thailand, Safari Park is flourished based on forest and marine feature combine which somewhat different from Bangladesh and India (Husain et al.1990). In Indonesia, Safari Park contain marine and island features with rainforest due to world largest archipelago and diversified country after Brazil, combination of Asia and pacific bio-geographical characteristics. In Indonesia, ecotourism earnings from two sectors nature and culture with ratio of 60:40, potentiality to earn 980 million dollar from this sector per year nevertheless Indonesian territory is only $1.32 \%$ of the world but contain $10 \%$ plant species, $12 \%$ mammal, $16 \%$ reptile and amphibian, $17 \%$ bird, $25 \%$ fish and $15 \%$ insect of the world (Manurung 2002). Considering overexploitation of natural resources and over human pressure in Bangladesh, the Safari Park may be the best place for recreation along with protection and conservation of natural resources. Safari Park not only carries aesthetic value but also plays a role to protect biodiversity and provides source for research and education (Heming 1953).

\section{Category of visitors based on age groups, occupation and education level}

The ecotourists ratio was different in Dulahazra Safari Park based on different age groups: adult, young, juvenile and infant. The adult was remarkable and followed by young, juvenile and infant (Figure 2a). Moreover, different occupation people such as student, employed, unemployed, businessmen, farmer, daily labor, hawker and housewife were frequently visited the park with different ratio. The students were majority (31\%) and lowest is hawker (3.1\%), second highest was housewife (21.1\%) comparing to employed (18\%) and businessman $(13 \%)$. Unemployed $(6.2 \%)$ and daily labor $(6 \%)$ ratio were almost same (Figure 2b). Among educated visitors secondary level educated group was dominant $(27 \%)$ and followed by primary (24\%), higher secondary $(22 \%)$, graduate $(14 \%)$, post graduate $(10 \%)$ and illiterate (7\%) (Figure 2b). 


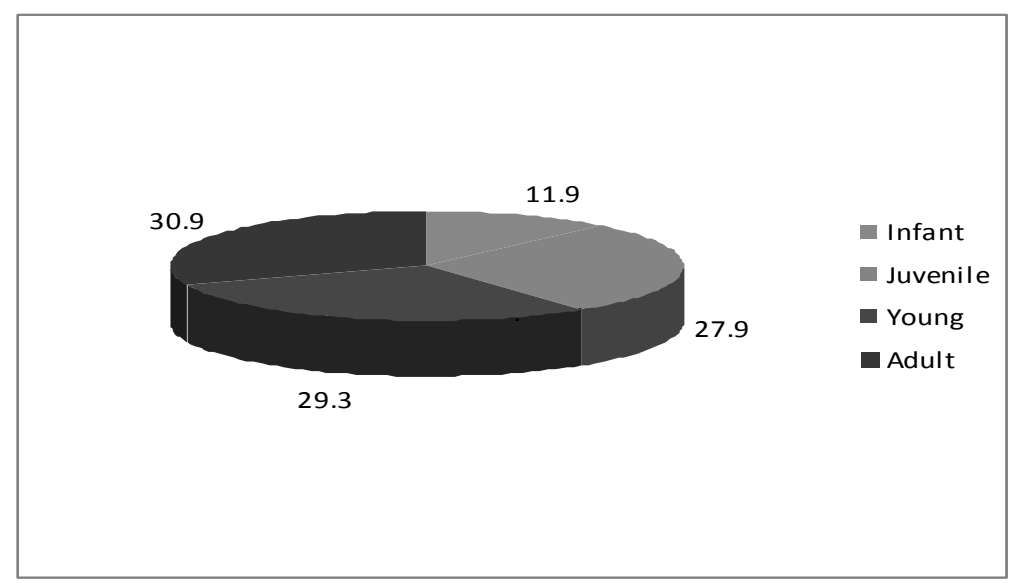

Fig 2a: Ecotourists categories based upon age-group

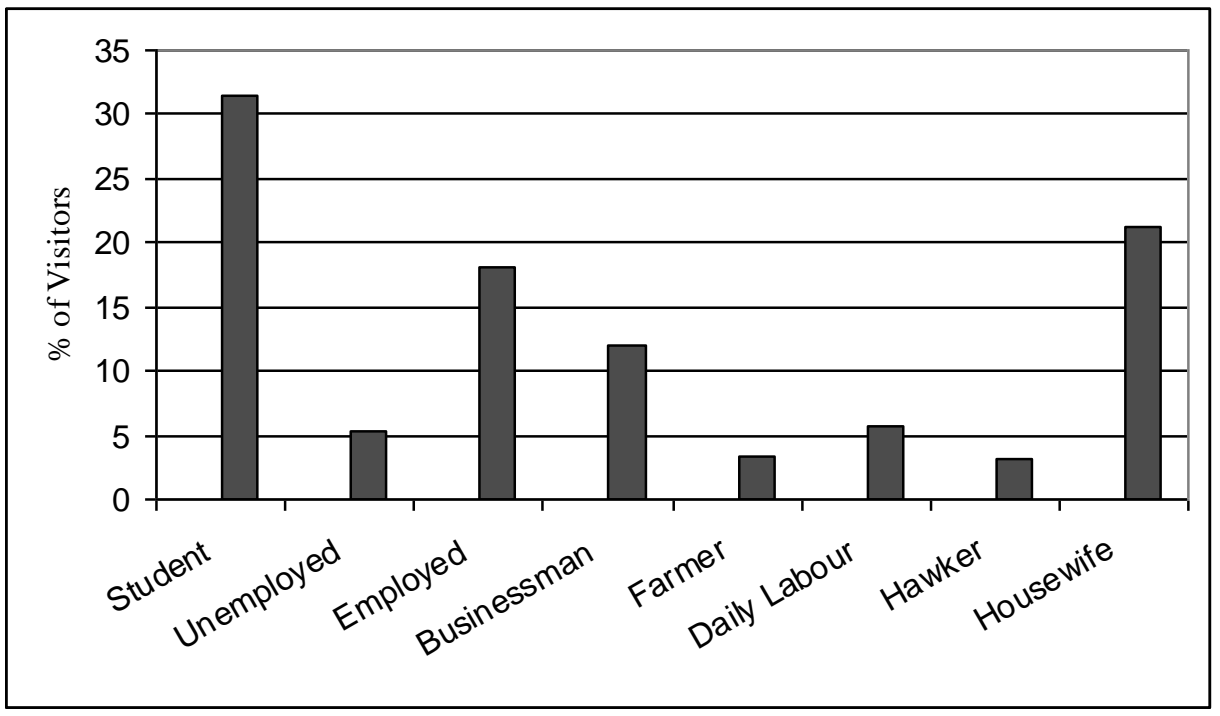

Fig 2b: Ecotourists from different occupations

\section{Visitor interests and their concept about Safari Park}

As Safari Park idea is being newly developed in Bangladesh, so people interest to Safari Park and their concept were measured based on their eagerness to park flora, fauna and topography even knowledge about Safari Park. The highest number of ecotourists was interested to park's captive and wild mammals $(36 \%)$, captive and wild birds $(21 \%)$, plants $(18 \%)$, and reptile both captive and wild (11\%). Ecotourists interest to amphibian and invertebrate were very negligible. Furthermore, different recreational sites of the study area also observed and found highest number of ecotourist visited animal oriented sites $(25 \%)$ and then natural lakes and streams (19\%), board walking (10\%) and watching tower (8\%). Overall, it was disappointed that maximum number of ecotourists (40\%) were in wrong concept while $24 \%$ were known slightly about Safari Park, $14 \%$ answer were satisfactory and $4 \%$ answer in good knowledge about Safari Park (figure 3c). 


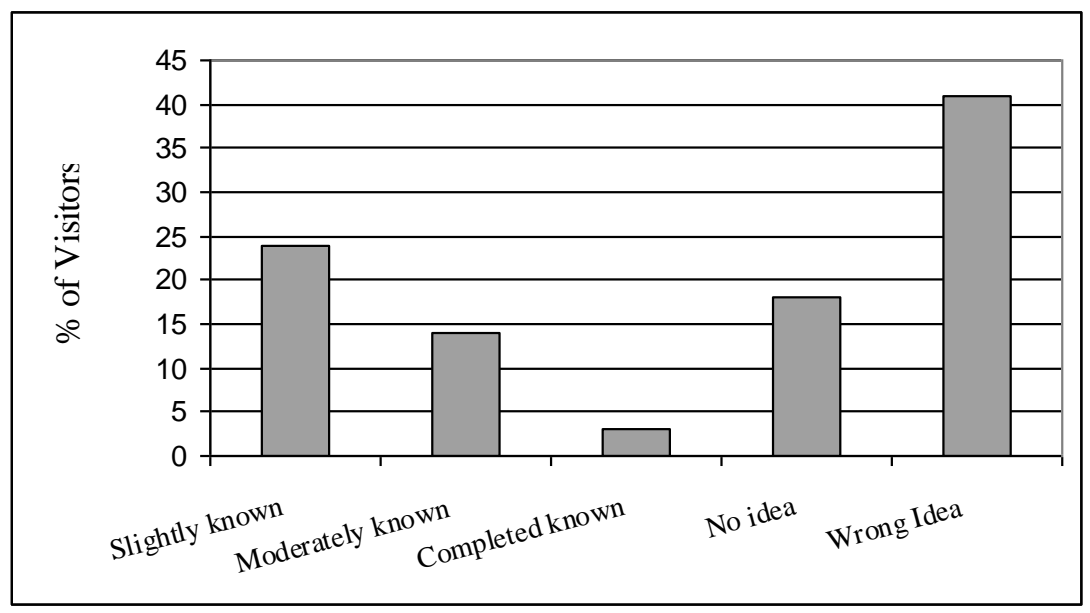

Fig 3c: Visitor perception about Safari Park

\section{Safari Park concept assists to protect topographical pristine, important flora and fauna}

The safari park concept not only used for recreation but also protect our incredible biodiversity with pristine topographical condition comparing to other types of park in our country. Since Bangladesh is a over populated country, so there is risk to be quick demolished her natural resources under extreme exhausted and disturbance pressure from many factors associated with overexploitation and consumption by people. As safari park hold dissected platform such as recreation and conservation, this concept may remedy to protect and conserve our valuable natural resources from merge extinction of many important natural resources. In India, many safari parks were established for conserving biodiversity hotspots for the purpose of protection of important flora and fauna.

\section{Species Conservation at Dulahazra Safari Park}

The Dulahazra Safari Park is being conserved eighty tree species, twenty shrubs species, twenty four climbers and twenty herb species in a natural environment. However, this park is considered the harbor of wildlife comparing to other protected areas in this region due to strict conservation policy and proper monitoring. Nine amphibian species, seventeen reptile species, more than one hundred bird species and twenty one mammal species are available here. None all these, many water depressions, live water stream, hilly topography are well protected inside the park.

According to Kelkar (2002), 15000 plants species out of 150000 and 75000 animals out of 1.5 million have their home in India due to diverse bio-geographical location. Many South-Asian countries are being emphasized to establish safari park for conservation purpose along with recreations which source of government revenue and improve local people socioeconomic status. Indonesia, the more biodiversity rich country in the Asia for its distinct characteristics and her many endemic plant and animal species are being conserved under safari park concept such as endemic Orang utans and Proboscies monkey for their conservation priority (Manurung 2002). In many Asian countries marine safari is being popular for the purpose of such activities. The Bangkok marine safari in Thailand is more fascinated and conserves sites (Sriphnomya 2002).

\section{Safari Park the source of revenue, education and research}

Safari park holds a vital role to explore research and education facilities consisting recreational and conservation opportunities. Local communities near safari park as well as government receive financial benefits through ecotourism. Since education and research opportunity and revenue flow circulated based on safari park, so well structure and nature oriented safari park can be consider nation asset. Every year many students and researchers visit Dulahazra Safari Park for education and research purposes. The quantities are being increased year to year comparing to other national parks and eco-parks in this country (Rahman 2007, Rahmatullah 2007). Students who visited the Dulahazra Safari Park can acquire huge knowledge on nature by easy means. Government revenue collection rises continuously because every year a large number of national and international ecotourists are visiting there. 
India employed 21.1 million people and its revenue range was 10418-11264 crore rupees in the fiscal of 1996-1997 from ecotourism sector (Kelkar 2002). Other Asian countries namely Indonesia, Malaysia and Thailand earn remarkable revenues from tourism sector behind nature protection and national reserve increase. According to Samsuddin et al. (1997), every year many ecotourists visit Sumatra to observe rich biodiversity, rafting, bird watching which main income flow of local communities. Indigenous communities in Bali are engaged to traditional businesses like buttick, handicraft, woodcarving, cooking and herbal medicine. These countries are protecting biodiversity along with enhance revenue flow by this way of conservation practice. Many African and South American countries are being developed education and research policies as well as revenue enhance strategies towards sustainable ecotourism.

\section{Ecotourism to International}

Ecotourism is being counted as a fast growing industry in the developing world and marked much more return (Sultan 2001). In the United States 30-40 million people payout billion of dollar per year comparing to Australian and European ecotourists (Sarker 1992). Ecotourism is the most popular in South America for Amazon forest, Africa for Savanna, Asia for marine, tropical rainforests, etc. Marine based ecotourism is most popular in Asia Pacific region and wildlife in African region.

\section{Ecotourism to Bangladesh}

The diversified topography in Bangladesh including the riverine flat alluvial plain, hills and valley, forest, lakes, sea and beaches, evergreen landscapes are simplified unique and fascinating to boost ecotourism comparing to other Asian countries. Different regions offer distinctive tourism attraction to ecotourists. Northwestern region hold lot of ancient archaeological sites which embodied of rich Buddhist and Muslim cultural heritages. The northeastern region is famous for undulated landscapes and lot of big water depressions. Most undulated landscapes contain panoramic view of tea garden. Water depressions are full of aquatic resources e.g. flora and fauna. The southeastern region decorated by green and semi-green hilly environment, forests and lakes. In addition, this region is tribal oriented, so, it has extra attraction. The southwest region holds vast seashore and mangrove forest with rich diversified ecosystem.

\section{Ecotourism to Safari Park}

There is a potentiality of flourish ecotourism in the Dulahazra Safari Park due to its incredible natural beauty, undulated landscape, water depression, streams, lakes, rich wildlife and good vegetation. The suitable location and enough accommodation facilities can enhance national revenue collection from this sector (Chowdhury et al. 2004). The diversification of wildlife and plant species in this park considered the main attraction behind ecotourism flourish.

Tourism criticism for the negative impacts on the cultural heritage and the environment of the area resulted in severe environmental degradation especially ecological sensitive areas. As ecotourism counted green productivity which significance a new paradigm of socio-economic development aimed at pursuing economic and productivity growth while protecting the environment. Ecotourism and green productivity have been constructed and applied as sets of theories and practices for the $21^{\text {st }}$ century. Tourists need food, water, shelter and energy at their tourism destinations. Natural resources are extracted from soil, forests and oceans to provide these goods and services. The environment becomes a sources of supply to the tourist not only consume but also create wastes which the environment has to assimilate if human activity is to be sustainable. A healthy sustainable environment is dependent on a healthy, sustainable environment practice. Therefore, ecotourism consider as goods and services which provide us livelihoods and service satisfaction. The Safari Park can be core destination to ecotourists regarding education and research in addition to recreation.

\section{References}

Balmforth, E.G. 1987. Draft management plan for Cox's Bazar Forest Division, 19861995 period. Forest Department. Govt. of the People's Republic of Bangladesh, Dhaka. pp.120

Biwas, S.R. 2001. Structure composition and diversity of tree species in Idgaon Forest Reserve of Cox's Bazar Forest Division Bangladesh. Forest Department. Govt. of the People's Republic of Bangladesh, Dhaka. Review paper. IFPSUU. pp 60.

Cater, E. 1994. Ecotourism in the Third World problems and prospects for sustainability. Oxford Univ. Press. London. pp 86. 
Chowdhury, J., S.R. Biswas, M.S. Islam, O. Rahman and S.N. Uddin 2004. Biodiversity of the Dulahazara Safari Park. Cox's Bazar, IUCN- Bangladesh Country Office. pp 61.

Dey, T. K. 2002. Dulahazra Safari Park, Cox's Bazar (Second phase) Development project wild life management and natural conservation divisional office. Bangladesh Forest Research Campus, Sholoshahar, Chittagong. 24 pp.

Drake, S. 1991. Development of a local participation plan for ecotourism projects. Oxford Univ. Press. London. pp 39.

Heming, E.W. 1953. Go wild at Windsor. Windsor Safari Park Retrieved on 2007. Windsor Publication. London. pp 70.

Husain, K.Z, S.U. Sarker, K. Rahman and M.N. Hoque 1990. Birds of the Dulahazra Deer Breeding Center, Cox's Bazar Forest Division. Bangladesh J. Zool. 18(1): 107-114.

Kelkar, O.P. 2002. Ecotourism and green productivity in India. Linking green productivity to ecotourism, Asian productivity organization, Tokyo. pp.54-62.

Manurung, R. 2002. Ecotourism in Indonsia. Linking green productivity to ecotourism. Asian productivity organization, Tokyo. pp 98-103.

McCormick, K. 1994. Can ecotourism save the rainforests? Rainforest Action Network. pp 63.

Rahman, M.M. 2007. The assessment of carrying capacity and ecotourism potentiality of Dulhazara Safari Park, Chakaria, Cox's Bazar. Unpublished, M.S. Project Paper, University of Chittagong. pp 94.
Rahmatullah, S. 2007. Ecotourism potentiality and its impact on local community of Dulhazara Safari Park, Chakaria, Cox's Bazar. Unpublished, M.S. Project Paper, University of Chittagong. pp 65.

Samsuddin, A. R., U. Hamzah, R. A. Rahman, C. Siwar, M. F. Mohd., J. Othman and R. Othman 1997.Thermal springs of Malaysia and their potential development. J. Asian Earth Sci,. 15 (2-3): 275-284.

Sarker, S.U. 1992. Parks and wildlife management development of professional in the forestry sector. UNDP/FAO/ Bangladesh 85/011 No. 52: 193.

Shamsuddoha, M. and T. Nasir 2011. Eco-tourism: A descriptive study on Sitakunda Ecopark in Chittagong division of Bangladesh. International J. Educational Res. and Tech., 2(1): 8-13.

Sriphnomya, E. 2002. Ecotourism policy in Thailand. Linking green productivity to ecotourism, Asian Productivity Organization. Tokyo. pp. 236- 241.

Sultana, I. Z. 2001. Tourism industries in Bangladesh and world tourism day 2001. The Bangladesh Observer weekend Magazine, Dhaka. pp 42.

Thampi, J. 2005. Ecotourism in Kerala, India: Lessons from the Eco-Development project in Periyar Tiger Reserve. ECOCLUB.com E-Paper Series, 13: 110. 